\title{
Effect of the crude protein level on the utilization of untreated and formaldehyde-treated urea in vitro
}

\author{
JOUKO SETÄLÄ and LIISA SYRJÄLÄ-QVIST
}

Department of Animal Husbandry, University of Helsinki, 00710 Helsinki
71, Finland

\begin{abstract}
Utilization of untreated urea $\left(\mathrm{F}_{0}\right)$ and urea treated with $1.5 \%$ formaldehyde $\left(\mathrm{F}_{1.5}\right)$ was tested in vitro on incubation substrates with different levels of crude protein: $9,10,11,12,13,14,15$ and $16 \%$ of the substrate dry matter. The content of crude protein was adjusted by addition of urea, the lowest level ( 9 $\%$ ) being that of the substrate without urea.

The incubation time was five hours. When $\mathrm{F}_{0}$ urea was used microbial protein synthesis, determined by tungstic acid-sulphuric acid precipitation, reached its maximum at the crude protein level of $11 \%$. When $F_{1.5}$ urea was added, the synthesis increased up to the level of $15 \%$ crude protein. At the levels of $13-15 \%$ crude protein, the synthesis was significantly $(P<0.05)$ higher with $F_{1.5}$ urea than with $F_{0}$ urea.

In the bacterial mass obtained by ultracentrifugation the content of methionine was significantly higher $(\mathrm{P}<0.01)$ when treated urea was used. With untreated urea, the proportion of lysine was significantly higher $(\mathrm{P}<0.05)$. Addition of urea did not affect the amino acid composition of the bacterial mass but increased the yield of microbial protein during incubation.
\end{abstract}

\section{Introduction}

In many of the papers reviewed by MØLLER (1979) rumen ammonia concentration has been shown to be a critical factor for ammonia utilization in the rumen, when the basal ration is supplemented with urea. Since the ammonia level in the rumen is chiefly dependent on the nitrogen intake and hence on the nitrogen content of the ration, it has been suggested that addition of urea is not justified in rations whose crude portein content exceeds $13-14 \%$ of dry matter (SATTER and SLYTER 1974).

However, the critical crude protein level can vary considerably, depending on such factors as the solubility and degradability of the nitrogen in the basal ration (AITCHISON et al. 1976, ROY et al. 1977) and the content and quality of energy in the ration (MØLLER 1973, SATTER and ROFFLER 1976, KROPP et al. 1977). The object of this experiment was to study how urea utilization is affected by the rate of urea degradation on diets with different levels of crude protein and a constant energy content. 


\section{Materials and methods}

The incubation technique was the same as used by SETÄLÄ and SYRJÄLÄQVIST (1982). The urea supplements consisted of untreated urea $\left(\mathrm{F}_{0}\right)$ and urea treated with $1.5 \%$ formaldehyde $\left(\mathrm{F}_{1.5}\right)$. The formaldehyde treatment was as described earlier (SETÄLÄ and SYRJÄLÄ-QVIST 1982).

The crude protein levels were $9,10,11,12,13,14,15$ and $16 \%$ of the substrate dry matter. The crude protein content was adjusted by adding urea to the substrate to be fermented. The first level was the content of the $\mathrm{NaOH}$-treated wheat straw and barley-molassed beet pulp mixture used as substrate (SETÄLÄ and SYRJÄLÄ-QVIST 1982).

The criterion of urea utilization was the formation of protein precipitable with tungstate - sulphuric acid during five hours' incubation. After incubation the fermentor contents were centrifuged at $2000 \mathrm{rpm}$ for 10 minutes, the sediment was discarded and protein was determined on the supernatant according to SETÄLÄ and SYRJÄLÄ-QVIST (1982).

The bacterial mass was separated from the supernatant without precipitation by ultracentrifugation at $25000 \mathrm{rpm}$ for 20 minutes (ARNOULD et al. 1976). This was done at the levels of $9,11,14$ and $15 \%$ of crude protein. The mass was analyzed for amino acids, excluding cysteine and tryptophan, by hydrolysis with $6 \mathrm{~N} \mathrm{HCl}$ at $110^{\circ} \mathrm{C}$ for 24 hours.

Statistical analyses were performed with a MONROE 1860 computor and its statistical programs. Both analysis of variance and the t-test were used. The differences between treatment means were tested with the Tukey test (STEEL and TORRIE 1960).

\section{Results}

The addition of urea to the substrate increased microbial protein synthesis (Fig. 1). When untreated urea $\left(F_{0}\right)$ was used, the peak value for synthesis was reached at the level of $11 \%$ crude protein. With the treated urea $\left(\mathrm{F}_{1.5}\right)$ protein synthesis was lower than with the untreated urea up to the level of 13 $\%$ crude protein. After this level microbial protein synthesis increased in the $F_{1.5}$ incubations and the peak of synthesis was not reached until the level of $15 \%$ crude protein. At the levels of $13-15 \%$ crude protein, synthesis was significantly $(P<0.05)$ higher with $F_{1.5}$ urea than with Fo urea.

The addition of urea to the substrate did not change the amino acid composition of the bacterial mass (Table 1). The proportions of isoleucine and leucine in the total amino acids tended to increase, but this change was not statistically significant.

When the incubations were performed with treated urea, the proportion of methionine in the amino acids was significantly $(\mathrm{P}<0.01)$ higher than when untreated urea was used. On the other hand, the proportion of lysine was significantly $(\mathrm{P}<0.05)$ lower than in incubations with untreated urea. There were also some differences in the proportions of threonine, proline and leucine but these were not statistically significant. 


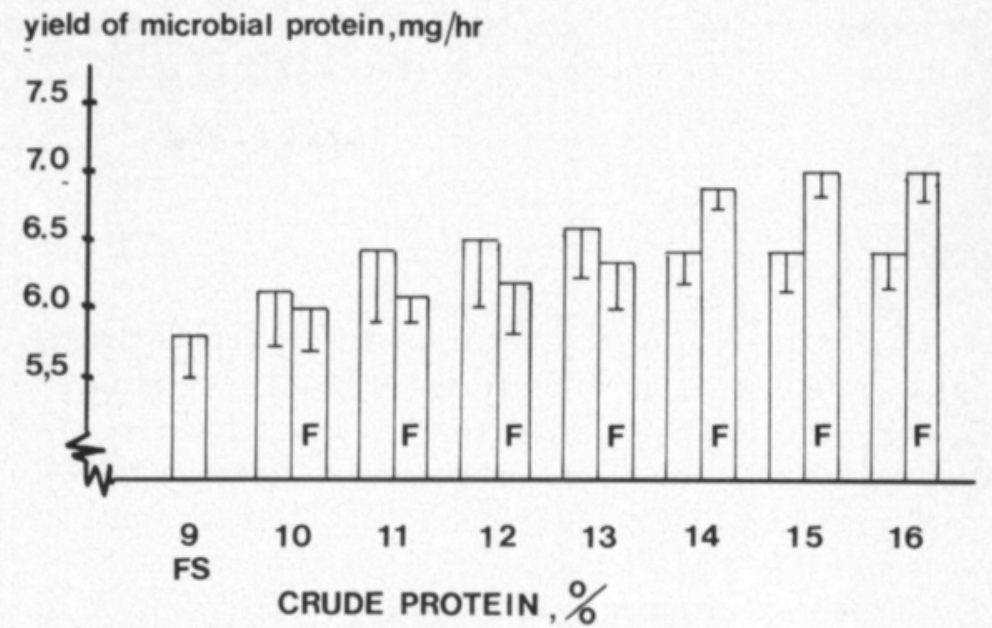

Figure 1. Effect of crude protein level on microbial protein yield ( $\mathrm{mg} / \mathrm{hr} / 40 \mathrm{mg}$ fermentor contents), when untreated or formaldehyde-treated urea was used.

$\mathrm{FS}=$ feed substrate, no urea, $\mathrm{F}=$ formaldehyde-treated $(1.5 \%)$ urea.

Table 1. Effect of crude protein level and added urea on the amino acid composition of the bacterial mass, when untreated $\left(\mathrm{F}_{0}\right)$ and treated $\left(\mathrm{F}_{1.5}\right)$ urea were used.

\begin{tabular}{|c|c|c|c|c|c|c|c|c|c|}
\hline & \multicolumn{3}{|c|}{ Untreated urea } & \multicolumn{3}{|c|}{ Treated urea } & \multirow{3}{*}{$\begin{array}{c}\text { Untreated } \\
\text { urea } \\
\overline{\mathrm{X}}\end{array}$} & \multirow{3}{*}{$\begin{array}{c}\text { Treated } \\
\text { urea } \\
\bar{x}\end{array}$} & \multirow{3}{*}{$\begin{array}{c}\text { No urea } \\
\bar{x}\end{array}$} \\
\hline & \multicolumn{6}{|c|}{ Level of crude protein, \% of DM } & & & \\
\hline & 11 & 14 & 15 & 11 & 14 & 15 & & & \\
\hline & \multicolumn{6}{|c|}{$\%$ of total amino acids } & & & \\
\hline Essential & 45.8 & 45.7 & 44.9 & 44.2 & 45,8 & 45,4 & 45.4 & 45.1 & 44.1 \\
\hline Arginine & 2.9 & 2.5 & 2.7 & 2.6 & 3.3 & 2.7 & 2.7 & 2.8 & 2.7 \\
\hline Histidine & 1.9 & 2.2 & 1.8 & 1.9 & 1.9 & 1.9 & 1.9 & 1.9 & 1.8 \\
\hline Isoleucine & 5.9 & 6.3 & 5.6 & 5.9 & 6.0 & 6.3 & 5.9 & 6.0 & 5.6 \\
\hline Leucine & 8.2 & 8.6 & 8.2 & 8.1 & 8.0 & 8.6 & 8.0 & 8.2 & 7.4 \\
\hline Lysine & 9.1 & 9.1 & 8.3 & 8.1 & 7.4 & 8.1 & $8.8^{\mathrm{a}}$ & $7.8^{\mathrm{b}}$ & $8.6^{\mathrm{ab}}$ \\
\hline Methionine & 0.9 & 0.6 & 0.7 & 1.0 & 1.3 & 1.3 & $0.7^{\mathrm{d}}$ & $1.2^{e}$ & $0.9^{d e}$ \\
\hline Phenylalanine & 5.3 & 5.1 & 5.4 & 5.3 & 5.5 & 5.2 & 5.2 & 5.3 & 5.4 \\
\hline Threonine & 6.3 & 6.6 & 6.8 & 6.1 & 7.1 & 6.0 & 6.6 & 6.3 & 6.4 \\
\hline Valine & 5.3 & 5.7 & 5.4 & 5.2 & 5.3 & 5.3 & 5.4 & 5.3 & 5.3 \\
\hline Non-essential & 54.2 & 54.3 & 55.1 & 55.8 & 54.2 & 54.6 & 54.6 & 54.9 & 55.9 \\
\hline Alanine & 6.6 & 6.9 & 6.8 & 7.0 & 6.9 & 6.9 & 6.7 & 6.9 & 7.2 \\
\hline Glutamic acid & 16.0 & 15.6 & 16.5 & 16.4 & 16.3 & 15.8 & 16.0 & 16.2 & 16.3 \\
\hline Glycine & 5.2 & 5.4 & 5.3 & 5.4 & 5.4 & 5.3 & 5.2 & 5.3 & 5.5 \\
\hline Proline & 3.6 & 4.4 & 4.2 & 3.5 & 3.4 & 3.9 & 4.0 & 3.6 & 3.6 \\
\hline Serine & 4.9 & 4.8 & 5.0 & 5.1 & 5.1 & 4.9 & 4.9 & 5.0 & 5.0 \\
\hline Tyrosine & 4.7 & 4.7 & 4.7 & 4.6 & 4.6 & 4.6 & 4.7 & 4.6 & 4.7 \\
\hline
\end{tabular}

$a-b(P<0.05), d-e(P<0.01)$, differences between means with different letters were statistically significant.

The ratio of essential to non-essential amino acids was not significantly changed by the addition or the treatment of urea. There was a tendency, however, for the proportion of the essential amino acids to be higher when untreated or treated urea was added to the substrate. The proportion of the 
non-essential amino acids tended to be higher when microbial protein synthesis did not increase with a rise in the amount of urea and the crude protein level.

\section{Discussion}

When untreated urea was used, the results for microbial protein synthesis agreed fairly well with the observations of SATTER and SLYTER (1974), KAUFMANN (1977) and SLYTER et al. (1979). Since the energy level was kept constant, lower degradation of urea was the main factor influencing the ratio between ammonia and energy to be fermented. The peak value for microbial protein synthesis was reached when untreated and treated urea constituted 18 and $35 \%$ of the total nitrogen in the substrate, respectively. If the ammonia levels are calculated according to the results obtained earlier (SETÄLÄ and SYRJÄLÄ-QVIST 1982) for the feed substrate alone and for both kinds of urea, the optimum ammonia concentration was $10-11 \mathrm{mmol} \mathrm{NH}_{3} / 1$, which is higher than those suggested elsewhere, for instance in the review by MØLLER (1979).

Energy is very important when ammonia utilization is concerned (MØLLER 1973, KROPP et al. 1977). For instance, EDWARDS and BARTLEY (1979) showed in vitro that urea, given in the form of starea, was efficiently utilized for protein synthesis, when the crude protein level was elevated from 17 to 30 $\%$ of dry matter. The fermentation of energy was shown to reach its maximum at the ammonia level of $11-12 \mathrm{mmol} \mathrm{NH}_{3} / 1$ (MEHREZ et al. 1977). In the present sudy, where the energy level was kept constant, the maximum in fermentation was evidently reached when no increase in microbial protein synthesis was found. Further addition of urea to the substrate gave too much ammonia in relation to the energy fermented and thus did not improve protein synthesis (McMENIMAN et al. 1976, HAGEMEISTER et al. 1980).

The amino acid composition of the bacterial mass was similar to that reported by SALTER et al. (1979), SYVÄOJA and KREULA (1979) and HVELPLUND and MØLLER (1980) for animals receiving urea-containing diets, although the proportion of methionine was rather low. According to SYVÄOJA and KREULA (1979), addition of urea caused slight changes in the proportions of threonine, glutamic acid, alanine, tyrosine and arginine in microbial protein. SALTER et al (1979) found that elevated levels of urea in the diet decreased the proportion of methionine.

The differences in the amino acid composition of the microbial mass found in this experiment between the diets probably arose from differences in the biosynthesis of amino acids. CHALUPA et al. (1970) reported that amination and transamination are the major mechanisms of ammonia assimilation by rumen microbes. Lysine, together with threonine and tryptophan, was synthesized through routes other than transamination (BHATIA et al. 1979), but the transaminase activities of the rumen protozoal and bacterial fractions were suggested to be slightly higher with respect to methionine than lysine. 
The dominant enzyme in the biosynthesis reaction chain could be altered by the $\mathrm{NH}_{4}^{+}$level in the rumen. Glutamate synthase and glutamine synthase decreased in activity at high $\mathrm{NH}_{4}^{+}$concentrations (ERFLE et al. 1977). The activity of alanine amino transferase increased correspondingly. These changes may be of importance from the point of view of our results, because SALTER et al. (1979) suggested that glutamic scid and alanine, together with aspartic acid, can act as initial recipients for subsequent transfer to other amino acids in the chain of biosynthesis.

It was also reported by ALLISON and BRYANT (1963) that $R$. flavefaciensis can use the carbon of formate for methionine biosynthesis. If formaldehyde is degraded to formic acid by rumen microbes, as suggested by KAEMMERER and KERBER (1977), this could also contribute to the higher concentration of methionine in microbial protein when treated urea was used.

However the possibility cannot be excluded that in spite of careful preparation of the samples, some unsequestrated protozoa may have influenced the amino acid composition of the microbial protein (PURSER and BUECHLER 1966). Protozoal protein contains more lysine and less methionine than bacterial protein. The same authors have also observed that the bacterium $R$. albus has a relatively high methionine content in its cell protein. Since formaldehyde seemed to have a negative effect on protozoa in vitro (SETÄLÄ and SYRJÄLÄ-QVIST 1982), it is possible that in incubations with unteated urea some connection existed between the lysine content of microbial protein and precence of protozoa.

Contamination by feed particles and their effect in analysis have been discussed in the earlier paper of SETÄLÄ and SYRJÄLÄ-QVIST (1982).

\section{References}

AITCHISON, T. E., MERTENS, D. R., McGILLIARD, A. D. \& JACOBSEN, N. L. 1976. Effect of nitrogen solubility on nitrogen utilization in lactating dairy cattle. J. Dairy Sci. 59: 2056-2062.

ALLISON, M. J. \& BRYANT, M. P. 1963. Biosynthesis of branched-chain amino acids from branchedchain fatty acids by rumen bacteria. Arch. Biochem. Biophys. 101: 269-281.

ARNOULD, R., VERBACK, W., VANBELLE, M., PASTOR, C. \& BONGE, D. 1976. Le dosage de l'acote bacterien dans le rumen par mesure des fenours en acide diaminopimelique. Laboratoire de Biochemie de la Nutrition, publ. 15: 1-15.

BHATIA, S. K., PRADHAN, K. \& SINGH RANDHIR. 1979. Microbial transaminase activities and their relationship with bovine rumen metabolites. J. Dairy Sci. 62: 441-446.

CHALUPA, W., CLARK; J., OPLIGER, R. \& LAVKER, R. 1970. Ammonia metabolism in rumen bacteria and mucosa from sheep fed soybean protein or urea. J. Nutr. 100: 161-174.

EDWARDS, J. S. \& BARTLEY, E. E. 1979. Soybean meal or starea for microbial protein synthesis or milk production with rations above thirteen percent natural protein. J. Dairy Sci. 62: 732-739.

ERFLE, J. D., SAUER, F. D. \& MAHADEVAN, S. 1977. Effect of ammonia concentration on activity of enzymes of ammonia assimilation and on synthesis of amino acids by mixed rumen bacteria in continuous culture. J. Dairy Sci. 60: 1064-1072.

HAGEMEISTER, H., LÜPPING, W. \& KAUFMANN, W. 1980. Microbial protein synthesis and digestion in the high-yielding dairy cow. Recent advances in animal nutrition-1980, ed. Haresign W. p. 67-84. Butherworths.

HVELPLUND, T. \& MØLlER, P. D. 1980. Fodringens indflydelse på vombakteriernes kemiske sammansaetning. Stat. Husdyrbrugsforsøg Medd 310: 1-4. 
KAEMMERER, K. \& KERBER, H-J. 1977. Formaldehydgeschütztes Sojaprotein im Verträchlichkeitsversuch bei Ratten. DLG-Forschungsber. Tierern. 538004: 2-44.

KAUFMANN, W. 1977. Economic and other considerations governing decisions on the advisability of incorporating additional and new sources of protein and non-protein nitrogen into the diet of beef cattle (including fattening cattle). Protein and non-protein nitrogen for ruminants. p. 101-120. Pergamon Press.

KROPP, J. R., JOHNSON, R. R., MALES, J. R. \& OWENS, F. N. 1977. Microbial protein synthesis with low quality roughage rations: isonitrogenous substitution of urea for soybean meal. J. Anim. Sci. 46: 837-843.

McMENIMAN, N. P., BEN-GHEDALIA, D. \& ARMSTRONG, D. G. 1976. Nitrogen -energy interactions in fermentation. Protein metabolism and nutrition. EAAP publ. 16: $217 \cdot 227$.

MEHREZ, A. Z., ØRSKOV, E. R. \& McDONALD, I. 1977. Rates of rumen fermentation in relation to ammonia concentration. Br. J. Nutr. 40: 337-347.

MØLLER, P. D. 1973. The influence of different carbohydrate sources on the utilization of urea nitrogen by lactating cows. 412. Beretn. Landøkon. Forsogslab., Copenhagen. 204 p.

- 1979. Non-protein nitrogen utilization by the ruminant. Protein utilization in farm animals, Tune, Denmark. 19 p.

PURSER, D. B. \& BUECHLER, S. M. 1966. Amino acid composition of rumen organisms. J. Dairy Sci. 49: 81-84.

ROY, J. H. B., BALCH, C. C., MILLER, E. L., ØRSKOV, E. R. \& SMITH, R. H. 1977. Calculation of the N-requirement for ruminants from nitrogen metabolism studies. Protein metabolism and Nutrition. p. 126-129. Netherlands.

SALTER, D. N., DANESHVAR, K. \& SMITH, R. H. 1979. The origin of nitrogen incorporated into compounds in the rumen bacteria of steers given protein - and urea - containing diets. Br. J. Nutr. 41: 197-209.

SATTER, L. D. \& SLYTER, L. L. 1974. Effect of ammonia concentration on rumen microbial protein production in vitro. Br. J. Nutr. 32: 199-208.

SATTER, L. D. \& ROFFLER, R. E. 1976. Relationship between ruminal ammonia and non-protein nitrogen utilization by ruminants. Tracer studies on non-protein nitrogen for ruminants III. p. 119-138. IAEA, Vienna.

SETÄLÄ, J. \& SYRJÄLÄ-QVIST, L. 1982. The degradation and utilization of formaldehyde-treated urea by rumen microbes in vitro. J. Scient. Agric. Soc. Finl. 54: 15-24.

SLYTER, L. L., SATTER, L. D. \& DINIUS, D. A. 1979. Effect of ruminal ammonia concentration on nitrogen utilization by steers. J. Anim. Sci. 906-912.

STEEL, R. G. \& TORRIE, J. H. 1960. Principles and procedures of statistics. New York 481. p.

SYVÄOJA, E-L. \& KREULA, M. 1979. The in vitro determination of the protein quality of rumen micro-organisms of cows on urearich feed. J. Scient. Agric. Soc. Finl. 51: 68-78.

Ms received March, 3, 1982. 


\title{
Rehuannoksen raakavalkuaistason vaikutus käsittelemättömän ja form- aldehydi-käsitellyn urean hyväksikäyttöön in vitro
}

\author{
Jouko Setälä ja Liisa Syrjälä-Qvist
}

Helsingin yliopiston kotieläintieteen laitos, 00710 Helsinki 71

Tutkimuksessa verrattiin rehuannoksen raakavalkuaistason vaikutusta käsittelemättömän urean ja 1.5 prosentin formaldehyditasolla käsitellyn urean hyväksikäyttöön. Tutkitut raakavalkuaistasot olivat 9, 10, $11,12,13,14,15$ ja 16 prosenttia raakavalkuaista substraatin kuiva-aineessa. Raakavalkuaistasoa muutettiin urealisäyksen avulla. Perusrehusubstraatti ilman ureaa muodosti ensimmäisen tason.

Wolframaatti-rikkihappo -saostuksella määritetty mikrobiproteiinisynteesi viiden tunnin inkubaation aikana lisääntyi käsittelemätöntä ureaa käytettäessä 13 prosentin raakavalkuaistasolle saakka. Käsitellyllä urealla maksimiproteiinisynteesi saavutettiin vasta 15 prosentin raakavalkuaistasolla. Ureoiden välinen ero oli merkitsevä $(\mathrm{P}<0.05)$ yli 13 prosentin raakavalkuaistason jälkeen.

Ultrasentrifugoimalla saadun bakteerimassan metioniinipitoisuus oli merkitsevästi $(\mathrm{P}<0.01)$ korkeampi inkubaatioissa, joissa käytettiin käsiteltyä ureaa käsittelemättömällä urealla saatuihin tuloksiin verrattuna. Käsittelemättömällä urealla tehdyissä inkubaatioissa oli vastaavasti bakteerimassassa merkitsevästi $(\mathrm{P}<0.05)$ korkeampi lysiinipitoisuus. Urean lisäys rehusubstraattiin ei vaikuttanut mikrobivalkuaisen aminohappokoostumukseen, mutta lisäsi proteiinisynteesiä inkubaation aikana. 